\title{
Optimization of Protease from Aspergillus Niger under Solid-State Fermentation Utilizing Shrimp Shell Substrate
}

\author{
Chee Kuan Ooi ${ }^{1}$, Nazaitulshila Rasit ${ }^{1, *}{ }^{*}$, Wan Rafizah Wan Abdullah ${ }^{1}$ \\ 1 Faculty of Ocean Engineering Technology and Informatics, Universiti Malaysia Terengganu; 9w2ckq@gmail.com \\ (C.K.O.); nazaitulshila@umt.edu.my (N.R.); wanrafizah@umt.edu.my (W.R.W.A.); \\ * Correspondence: nazaitulshila@umt.edu.my;
}

Scopus Author ID 56516956900

Received: 10.02.2021; Revised: 9.03.2021; Accepted: 14.03.2021; Published: 31.03.2021

\begin{abstract}
Proteases, also known as proteinases or proteolytic enzymes, belong to a group of hydrolases. It can be applied in numerous fields and industries. Solid-state fermentation (SSF) is recognized as an effective method to produce protease. The ultimate aim of this study is to optimize the production of protease from Aspergillus niger under solid-state fermentation (SSF) by utilizing shrimp shell powder as a solid substrate. It was found that the produced protease from SSF was slightly alkaline. The correlation between factors operating parameters (incubation temperature, inoculum size, moisture content) for enzyme production is analyzed using statistical software, Minitab 16. A $2^{3}$ full factorial experimental design was employed, and the enzyme produced was optimized by the method of desirability function. The optimal conditions for protease production of $3.7 \mathrm{U} / \mathrm{mg}$ were $35{ }^{\circ} \mathrm{C}$ of incubation temperature, $60 \%$ of initial moisture content, and 1.0 inoculum size. It is concluded that SSF protease was successfully produced from Aspergillus niger by utilizing shrimp waste as substrate. Through optimization study, moisture content, the interaction between incubation temperature and moisture content, interaction between moisture content and inoculum size significantly impact protease production.
\end{abstract}

Keywords: protease; Aspergillus niger; shrimp shell; solid-state fermentation; optimization.

(C) 2021 by the authors. This article is an open-access article distributed under the terms and conditions of the Creative Commons Attribution (CC BY) license (https://creativecommons.org/licenses/by/4.0/).

\section{Introduction}

Proteases, also known as proteinases or proteolytic enzymes, belong to a group of hydrolases. It acts as a catalyst in the hydrolysis of protein to polypeptides and oligopeptides to amino acids [1-3]. Proteases account for approximately $60 \%$ of the whole industrial enzyme market and have wide-ranging applications in numerous fields and industries, including leather, detergent, food processing, textile, analytical, pharmaceutical, diagnostic, commercial, and waste treatment. Proteases can perform hydrolyzation of insoluble protein in the waste stream, while solubilization of meat and fish remains. Besides, protease utilization in wastewater treatment systems also improves sludge dewatering [1, 4-7].

Proteases can be produced from different sources, such as fungi, plants, animals, and microorganisms, by submerged or solid-state fermentation. A microbe is commonly used to produce proteases due to its feasibility in genetic manipulation, rapid growth rate, and wide biochemical diversity. Fungal species like Aspergillus, Penicillium, and Rhizopus are also generally used for proteases production as they are considered safe. Aspergillus niger is one of the main sources of fungal proteases [2, 8-10]. 


\subsection{Research background.}

Solid-state fermentation (SSF) is a fermentation process involving a solid matrix with a very low amount or without free water; however, there must be a sufficient amount of moisture in the substrate to support the metabolism and growth of microorganisms [11-13]. The solid matrix mentioned could be the source of nutrients or carbon utilized by the microorganisms to support the development, growth, and metabolic activities [14, 15]. Microorganisms excrete the required enzymes during SSF for the degradation of the substrate molecules [14]. The solid substrate and microorganisms' nature is the important parameter that influences the production yield and affects the SSF process [16].

Filamentous fungi are regarded as the most appropriate microorganisms for SSF. Fungi such as Aspergillus niger, Fusarium culmorum, and Penicillium can excrete significant amounts of enzymes and metabolites through SSF as this technique can stimulate their natural habitat. There are approximately $60 \%$ of commercially available enzymes produced from fungi. Yeasts are also suitable for SSF. Filamentous fungi and yeasts are able to grow in an environment with low water activity. Some species of bacteria, such as Bacillus thuringiensis, Pseudomonas sp., and Bacillus subtilis, have also been employed to produce the enzyme through SSF [12, 13, 17].

Practically all the fermentation processes were based on the concepts and theory of SSF as it played a very important role for humankind, mainly for food and beverages, both in western and eastern countries. In recent decades, SSF employing microorganisms for the production of biomolecules and has been applied in various industries and sectors, including textile, pharmaceutical, food, biochemical and bioenergy, and others [11, 13, 18]. SSF can be utilized and applied in a controlled way to produce value-added products, for example, enzymes [12]. Solid-state fermentation (SSF) has been claimed to have more significant advantages in enzyme production. It requires lower energy consumption and produces lesser wastewater. Furthermore, enzyme productions through SSF are less subjected to the effects of the $\mathrm{pH}$ of media and temperature and inhibition inhibition by the substrate $[11,18]$.

\subsection{Problem statement.}

It is vital to select suitable substrates for the production of enzymes under SSF. An appropriate solid material should be able to supply all the essential nutrients for the growth of microorganisms. Solid substrates also act as anchorage and physical support for the microbial cells. Lignin, starch, fibers, pectin, cellulose, and hemicellulose are the fundamental structure of solid substrates. These structures define the substrates' properties and characteristics and play the carbon and energy source's role for microorganisms' growth [11, 17-19]. Agroindustrial residues and shrimp by-products have been introduced as solid substrates to produce microbial extracellular enzymes as they are cheap and have low commercial value. These waste are available abundantly and can cause environmental problems if they are disposed of to the environment without any treatment [18, 20]. Agro-industrial residues [21], soybean hull [22], and okara [23] have been utilized for protease production by previous researchers. Bioconversion of these residues into commercially valuable products provides a considerable economic bonus, reduces the quantity of solid waste, and encourages environmentally-friendly agro-industrial waste management $[18,19]$.

Shrimp belongs to the family of Crustacea. It is one of the most favored harvests among crustaceans. Shrimp catches marked a new record in 2017 and 2018 at over 336,000 tonnes. 
Since 2005, global shrimp catches increase annually and have been stable since 2012 at 3.5 million tonnes, with Asia marked the most significant volume in shrimp fishing. Shrimp shells are an important group of by-products. It was categorized as a slow natural degradation rate of shells produced in high volumes due to the increased processing and production $[24,25]$. Nonedible parts of shrimp processing bio-wastes, including the shell, head and tail portions, occupy about $50-70 \%$ of the raw material's total volume. These bio-wastes are being generated tremendously due to the high demand for shrimp products. It has been reported that around 68 million tonnes of crustacean waste are generated annually. Severe environmental problems and impacts have arisen as a result of the continuous disposal of shrimp waste into the shore and coastal environment [26, 27].

Most of the shrimp wastes are discarded at will. According to the current level of awareness of society on the negative impact of pollution, shrimp waste can be utilized as a fermentation media and the production of high value-added and economically useful products. In the meantime, shrimp bio-waste utilization also plays a vital role in conserving and preserving a clean environment [20, 26, 28]. In the present study, enzymes are produced using shrimp shell powder as solid substrate under SSF. SSF is believed to possess several advantages over submerged fermentation $(\mathrm{SmF})$, such as higher enzyme production, higher product stability, lower demand on sterility, and lower protein breakdown [12].

\section{Materials and Methods}

\subsection{Microorganism and inoculum preparation.}

The fungus Aspergillus niger used in this study was isolated from the effluent of a domestic wastewater treatment plant in Universiti Malaysia Terengganu (UMT) [29]. The inoculums were inoculated in potato dextrose agar (PDA) media in a Petri dish at $30{ }^{\circ} \mathrm{C}$ for 4 days. Then, it was diluted with $500 \mathrm{ml}$ of distilled water. The spore suspension was stored in the chiller at $4{ }^{\circ} \mathrm{C}$ [30]. The inoculum size was calculated using Neubauer Chamber [31].

\subsection{Preparation and characterization of shrimp shell substrate.}

Unwanted shrimp shells were collected from a local seafood restaurant named Ocean Restaurant. Shrimp shells were removed as only the shrimp's flesh is needed to prepare dishes for this restaurant. The shrimp shells were then sent to the laboratory in an icebox. The shells were washed to remove dirt, sand, and soil from them. The washed shells were then dried in the oven at $55^{\circ} \mathrm{C}$ for 12 hours. The shells were then milled into powder form with a disk mill with a sieve size of $1.2 \mathrm{~mm}$. The shrimp shell powder was applied as the substrate for this study without any pre-treatment [20].

FTIR was conducted using IRTracer-100 Fourier Transform Infrared Spectrophotometer to characterize the sample powder. $\mathrm{KBr}$ pellets were prepared by mixing the sample powder with potassium bromide $(\mathrm{KBr})$ with the ratio of 1:10 and compressed into salt discs for scanning in the $400-4000 \mathrm{~cm}^{-1}$ spectral range $[32,33]$.

\subsection{Enzyme production under solid-state fermentation.}

The enzyme was produced using the SSF technique. 5 gram of substrate powder was moistened with $5.5 \mathrm{ml}$ of water in a conical flask and was autoclaved for 30 minutes at 15 psi pressure. The substrate medium was inoculated with $2 \mathrm{ml}$ of Aspergillus niger inoculum [20]. 
It was then incubated in an incubator at $30{ }^{\circ} \mathrm{C}$ for 120 hours [17]. After incubation, $50 \mathrm{ml}$ of water was added, and the content was shaken at a rotary shaker at $150 \mathrm{rpm}$ for 30 minutes at room temperature. The solution was then filtered through Whatman filter paper, and the supernatant was collected. It was centrifuged at $4,400 \mathrm{rpm}$ at $4{ }^{\circ} \mathrm{C}$ for 20 minutes. The supernatant was used for enzyme assays [20].

\subsection{Characterization of the enzyme.}

The protease activity of the enzyme produced was analyzed. In addition, the $\mathrm{pH}$ of the enzyme was also determined by using a $\mathrm{pH}$ meter.

\subsubsection{Protease assay.}

Protease activity was determined using the Casein Digestion Unit (CDU) Analytical Method [33], which is also named Spectrophotometric Stop Rate Determination. Casein was used as the substrate. Both test and blank conical flasks were added with $3 \mathrm{ml}$ of Casein, and only the test conical flask was added with $0.5 \mathrm{ml}$ of the enzyme. They were incubated for 10 minutes at $30{ }^{\circ} \mathrm{C}$ in the water bath. Both flasks were then added with $3.2 \mathrm{ml}$ of TCA, and 0.5 $\mathrm{ml}$ of distilled water was added into a blank conical flask. Incubation was done for 20 minutes at $37^{\circ} \mathrm{C}$. The samples were centrifuged at $4 \mathrm{rpm}$ for 15 minutes. The absorbance values of the prepared samples were measured using a spectrophotometer at $275 \mathrm{~nm}$.

Protease activity $=\frac{(\text { Absorbance value of })(\text { test }- \text { blank })(67)(\text { Dilution } \text { factor })}{10(1.34)(\text { volume of enzyme })}$

\subsection{Optimization of enzyme production.}

In this present study, a $2^{3}$ full factorial experimental design ( 3 represents the number of factors, 2 represents the number of levels) was employed using the statistical software Minitab 16 to study the interactions between the factors and their effects on the response. These three factors are incubation temperature, moisture content, and inoculum size. Each factor was studied at two levels: low level and high level, coded as -1 and +1 , respectively, as shown in Table 1. Solid-state fermentation was conducted at $25^{\circ} \mathrm{C}$ and $35^{\circ} \mathrm{C}$. The moisture content of the solid substrate was adjusted to $40 \%$ and $60 \%$. The inoculum size of Aspergillus niger was measured according to the Petri dish's number, which was 1 and 9.

Table 1. Values and levels of the factors in the $2^{3}$ factorial experimental design.

\begin{tabular}{l|c|c|c}
\multicolumn{2}{c}{ Factors } & Coded Symbol & \multicolumn{2}{c}{ Values of Coded Levels } \\
\cline { 3 - 4 } & & Low (-1) & High (+1) \\
\hline Incubation Temperature $\left({ }^{\circ} \mathrm{C}\right)$ & $\mathrm{X}_{1}$ & 25 & 35 \\
\hline Moisture Content $(\%)$ & $\mathrm{X}_{2}$ & 40 & 60 \\
\hline Inoculum Size (Petri dish) & $\mathrm{X}_{3}$ & 1 & 9
\end{tabular}

The software suggested a total of 24 experiment runs for data collection and analysis. Table 2 illustrates the factors and the levels for the experiments with real and coded values.

The polynomial equation based on the first-order model for this experimental design with three factors is given as below:

$Y=a_{0}+a_{1} X_{1}+a_{2} X_{2}+a_{3} X_{3}+a_{12} X_{1} X_{2}+a_{13} X_{1} X_{3}+a_{23} X_{2} X_{3}+a_{123} X_{1} X_{2} X_{3}$

where $Y$ is the experimental response, which represents the enzyme yield. $X_{1}, X_{2}$, and $X_{3}$ are the coded variables shown in Table 1 corresponding to incubation temperature, moisture content, and inoculum size, respectively. $X_{1} X_{2}, X_{1} X_{3}, X_{2} X_{3}$, and $X_{1} X_{2} X_{3}$ indicate the interactions between 
the factors. The coefficient $a_{0}$ implies the average value of the enzyme yield from the total experiment runs, $a_{1}, a_{2}$, and $a_{3}$ show the linear coefficients while $a_{12}, a_{13}, a_{23}$, and $a_{123}$ represent the interaction coefficient $[34,35]$.

Table 2. Design matrix of $2^{3}$ full factorial designs in real and coded values.

\begin{tabular}{|c|c|c|c|}
\hline \multirow[b]{2}{*}{$\begin{array}{c}\text { Experiment } \\
\text { number }\end{array}$} & \multicolumn{3}{|c|}{ Factors } \\
\hline & $\begin{array}{c}\text { Incubation Temperature } \\
\left({ }^{\circ} \mathrm{C}\right)\end{array}$ & $\begin{array}{c}\text { Moisture Content } \\
(\%)\end{array}$ & $\begin{array}{l}\text { Inoculum Size } \\
\text { (Petri dish) }\end{array}$ \\
\hline 1 & 35 & 60 & 9 \\
\hline 2 & 35 & 60 & 9 \\
\hline 3 & 25 & 40 & 1 \\
\hline 4 & 25 & 60 & 1 \\
\hline 5 & 35 & 40 & 1 \\
\hline 6 & 35 & 40 & 9 \\
\hline 7 & 25 & 60 & 1 \\
\hline 8 & 35 & 40 & 1 \\
\hline 9 & 35 & 40 & 9 \\
\hline 10 & 35 & 40 & 1 \\
\hline 11 & 35 & 60 & 1 \\
\hline 12 & 35 & 40 & 9 \\
\hline 13 & 25 & 60 & 1 \\
\hline 14 & 35 & 60 & 1 \\
\hline 15 & 35 & 60 & 9 \\
\hline 16 & 25 & 40 & 9 \\
\hline 17 & 25 & 60 & 9 \\
\hline 18 & 25 & 40 & 1 \\
\hline 19 & 25 & 60 & 9 \\
\hline 20 & 35 & 60 & 1 \\
\hline 21 & 25 & 40 & 9 \\
\hline 22 & 25 & 60 & 9 \\
\hline 23 & 25 & 40 & 1 \\
\hline 24 & 25 & 40 & 9 \\
\hline
\end{tabular}

The method of desirability function was then applied to acquire maximum production of protease [36].

\section{Results and Discussion}

\subsection{Characteristics of shrimp shell substrate.}

The shrimp shell powder's structural and functional properties were determined by FTIR spectra shown in Figure 1. It is found that strong absorbance bands are seen at 3141.00 $\mathrm{cm}^{-1}, 2939.52 \mathrm{~cm}^{-1}, 2353.16 \mathrm{~cm}^{-1}, 1643.35 \mathrm{~cm}^{-1}, 1411.89 \mathrm{~cm}^{-1}$ and $1068.56 \mathrm{~cm}^{-1}$. The FTIR spectrum of shrimp shell powder shows a band at $3141.00 \mathrm{~cm}-1$ representing amino peak and $\mathrm{N}-\mathrm{H}$ stretching vibration of amide group present in the protein [32, 37]. The peak observed at $2939.52 \mathrm{~cm}^{-1}$ indicating $\mathrm{CH}_{2}$ stretching and $\mathrm{CH}_{3}$ vibration, which also present in a protein molecule. It might also result from a long hydrocarbon chain of lipids and carotenoids that exist in dried shells [38, 39]. Shrimp shell powder also showed the characteristics at $2353.16 \mathrm{~cm}^{-1}$, representing asymmetric and symmetric $\mathrm{C}-\mathrm{H}$ stretching vibrations of amide-II linkage of protein $[37,40]$.

It is clearly noticed that a peak at $1643.35 \mathrm{~cm}^{-1}$ corresponded to the $\beta$-sheet structure of the protein [37]. Besides, weak peaks are observed at $1411.89 \mathrm{~cm}^{-1}$ and $1068.56 \mathrm{~cm}^{-1}$. The peak at $1411.89 \mathrm{~cm}^{-1}$ implying C-N stretching and $\mathrm{N}-\mathrm{H}$ bend of amide II linkage of the protein, while the peak at $1068.56 \mathrm{~cm}-1$ represents $\mathrm{C}-\mathrm{O}$ stretching vibration asymmetric bridge oxygen in the sample $[37,39]$. 


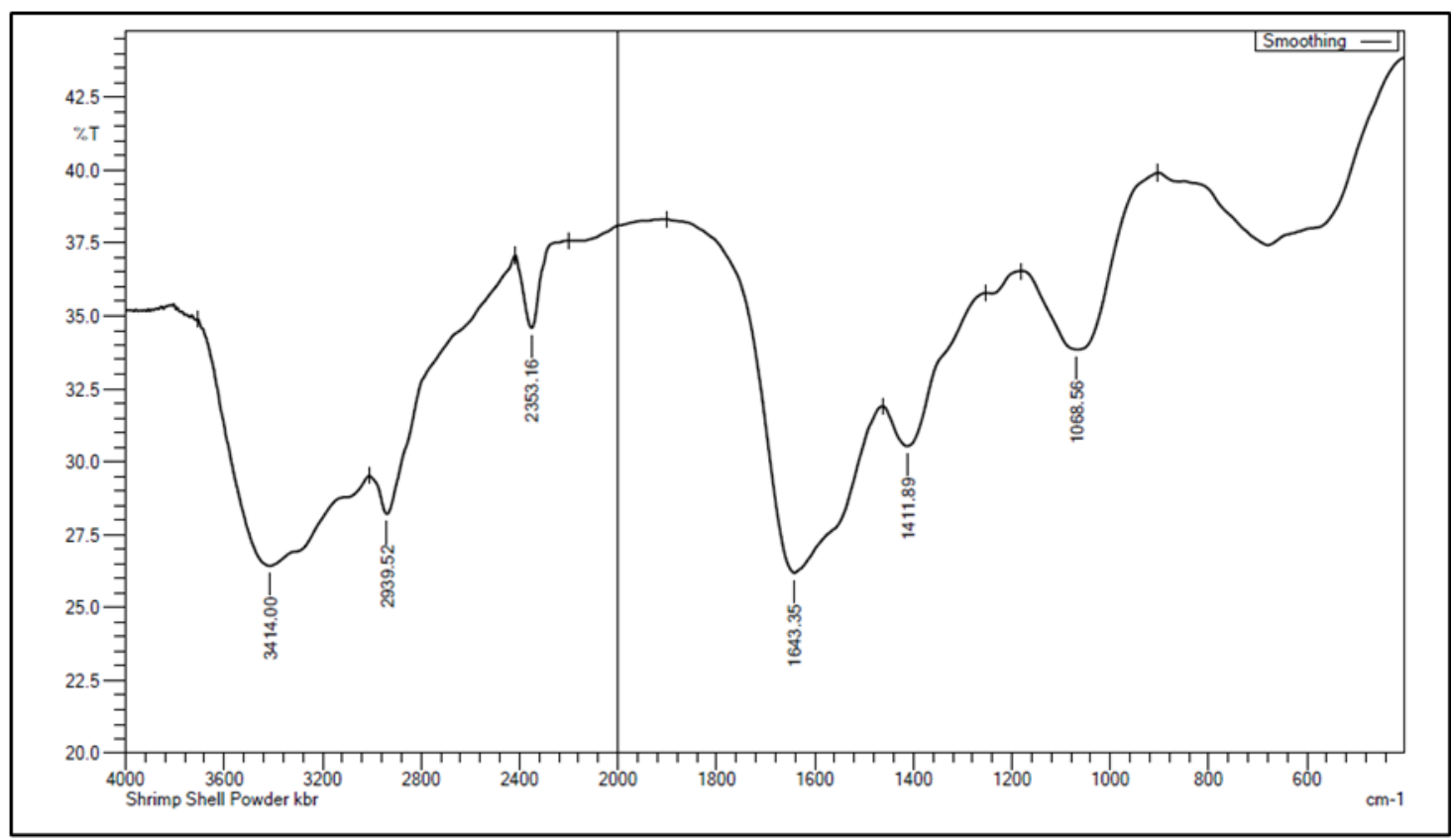

Figure 1. FTIR spectra of shrimp shell substrate.

\subsection{Characteristic of the enzyme.}

The $\mathrm{pH}$ value of the enzyme produced from Aspergillus niger by using shrimp shells as a substrate is slightly alkaline, which is 8.74 . The $\mathrm{pH}$ of dried shrimp by-products was $8.6 \pm$ 0.2 , according to the studies of [20]. It also contained protein, chitin, fat, and minerals. The shrimp by-product composition might differ from batch to batch due to various factors, including age, shrimp species, proportion of the shrimp body, and processing methods [20]. The inoculum size of the selected microorganism was calculated $1.59 \times 10^{6}$ pores $/ \mathrm{ml}$, using Neubauer Chamber.

The protease activity of the enzyme produced from SSF is $3.5 \mathrm{U} / \mathrm{ml}$. Previous studies $[27,41]$ utilized shrimp by-products to produce protease and lipase under submerged fermentation $(\mathrm{SmF})$. Various reports on enzyme production from Aspergillus niger are available, mostly applied agricultural or biomass waste as a solid substrate. The enzymes produced including protease [42], amylase [43], and lipase [44]. Nevertheless, to the best of our knowledge, there are no reports available regarding the production of protease from Aspergillus niger under SSF using shrimp shell powder as the solid substrate.

Shrimp shell is a suitable carbon/nitrogen $(\mathrm{C} / \mathrm{N})$ source for protease production through the fermentation process [28]. The exoskeleton of shrimp is rich in protein, minerals, chitin, and inorganic compound like calcium carbonate. Protein hydrolysate with well-balanced peptides and amino acid composition is allowed to be recovered from the microbial enzymatic digestion of this nutrient-rich waste $[45,46]$. Thus, shrimp shell powder is suitable to act as an inducer for protease production by Aspergillus niger, a protease-producing strain [45, 47].

\subsection{Full factorial design analysis.}

The experimental design matrix with actual values is shown in Appendix B. The factors involved are incubation temperature $\left(\mathrm{X}_{1}\right)$, moisture content $\left(\mathrm{X}_{2}\right)$ and inoculum size $\left(\mathrm{X}_{3}\right)$. Yield represents the response of the experiment, which is protease activity in the enzyme produced. 
Table 3 presents the model's coefficients, a standard deviation of each coefficient, and probability for the full $2^{3}$ factorials designs. By substituting the coefficients in Eq. (2) by their numerical values, we get:

$Y=2.7375-0.2292 X_{1}+0.3542 X_{2}-0.3208 X_{3}+0.2042 X_{1} X_{2}-0.1042 X_{1} X_{3}-0.1375 X_{2} X_{3}-$ $0.0708 X_{1} X_{2} X_{3}$

The coefficient of determination (R-Sq) for a good fit model should be closed to $100 \%$ or 1 and should be at least $80 \%$ or 0.80 [48]. From Table 3, the R-Sq value is $88.45 \%$. It suggests that the model was able to predict the response significantly.

Table 3. Estimated regression coefficients for protease production.

\begin{tabular}{l|c|c|c|c} 
Terms & Coefficients & SE Coef & T-value & $\boldsymbol{p}$-value \\
\hline Constant & 2.7375 & 0.05401 & 50.69 & 0.000 \\
\hline Incubation Temperature $\left(\mathrm{X}_{1}\right)$ & -0.2292 & 0.05401 & -4.24 & 0.001 \\
\hline Moisture Content $\left(\mathrm{X}_{2}\right)$ & 0.3542 & 0.05401 & 6.56 & 0.000 \\
\hline Inoculum Size $\left(\mathrm{X}_{3}\right)$ & -0.3208 & 0.05401 & -5.94 & 0.000 \\
\hline $\mathrm{X}_{1} \cdot \mathrm{X}_{2}$ & 0.2042 & 0.05401 & 3.78 & 0.002 \\
\hline $\mathrm{X}_{1} \cdot \mathrm{X}_{3}$ & -0.1042 & 0.05401 & -1.93 & 0.072 \\
\hline $\mathrm{X}_{2} \cdot \mathrm{X}_{3}$ & -0.1375 & 0.05401 & -2.55 & 0.022 \\
\hline $\mathrm{X}_{1} \cdot \mathrm{X}_{2} \cdot \mathrm{X}_{3}$ & -0.0708 & 0.05401 & -1.31 & 0.208 \\
\hline $\mathrm{R}-\mathrm{Sq}$ & \multicolumn{4}{|c}{$88.45 \%$} \\
\hline $\mathrm{R}-\mathrm{Sq}$ (prediction) & \multicolumn{4}{|c}{$74.01 \%$} \\
\hline $\mathrm{R}-\mathrm{Sq}$ (adjusted) & $83.40 \%$
\end{tabular}

\subsubsection{Main effects.}

From $\mathrm{Eq}$ (3), it was noted that the coefficient of $\mathrm{X}_{2}$ is positive. It can be verified that moisture content has a positive effect on the production of protease. It indicates that the production of protease increases as the moisture content increases.

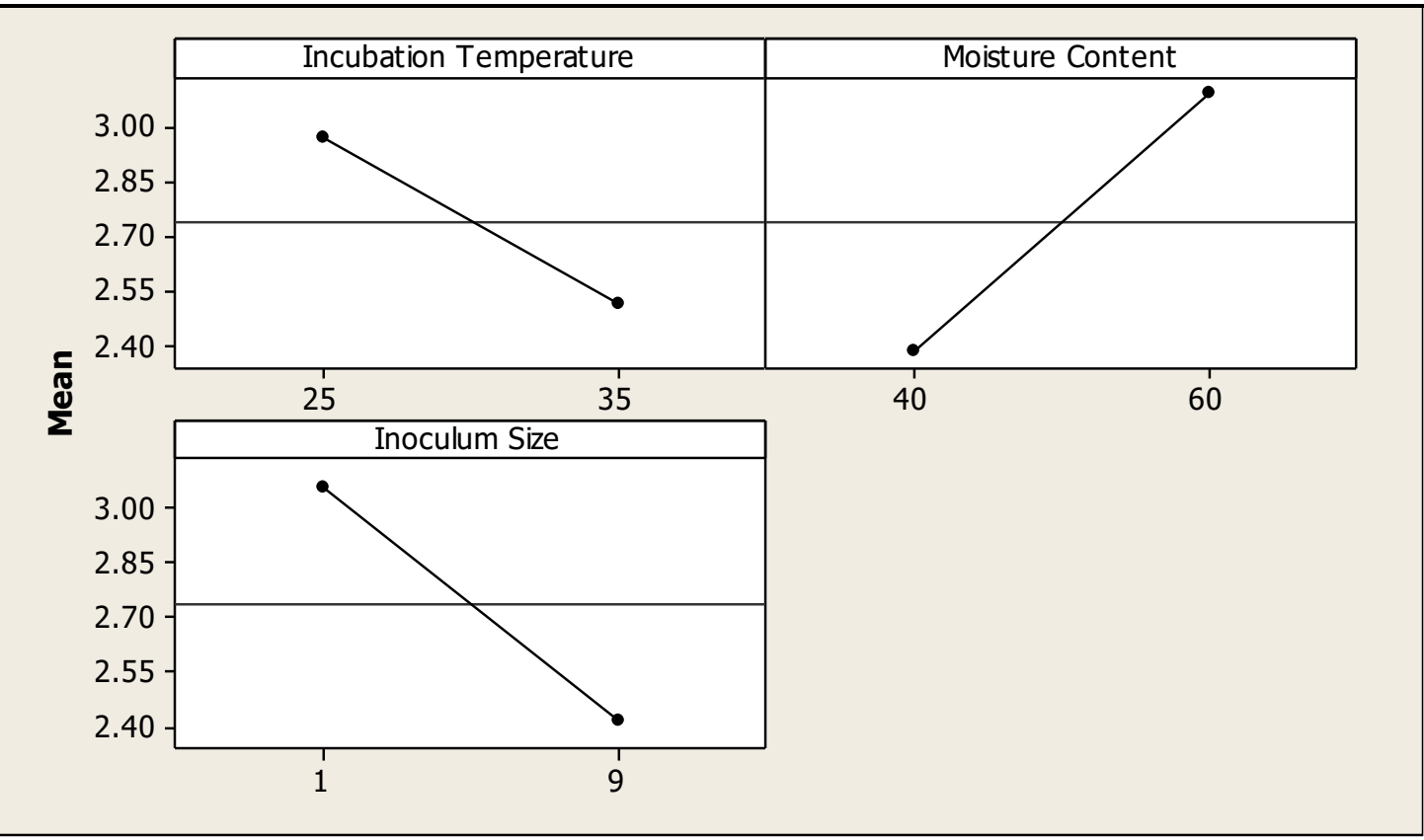

Figure 2. Main effects plot for protease production.

On the other hand, the regression coefficients of $X_{1}$ and $X_{3}$ are negative. It is acknowledged that incubation temperature and inoculum size have a negative effect on the production of protease. It implies that protease production increases when these two factors change from a greater extent to a lower extent. The $p$-values for both incubation temperature, 
moisture content, and inoculum size are lower than 0.05, as shown in Table 3 . The parameter with a $p$-value $<0.05$ has a significant effect on explaining the yield response [49].

All respective factors affect the response differently. The main effect's magnitude is larger if the slope is further away from zero [50]. From Figure 2, the steep slope shows that moisture content and inoculum size appear to have more notable effects on the production of protease compared to incubation temperature.

\subsubsection{Interaction effects between factors.}

As shown in Table 3 , the $p$-values for $\mathrm{X}_{1} . \mathrm{X}_{3}$ and $\mathrm{X}_{1} . \mathrm{X}_{2} . \mathrm{X}_{3}$ are larger than 0.05 . It reveals that the interaction between incubation temperature and inoculum size and the interaction between all three factors do not significantly impact the response. In contrast, the $p$-values for $\mathrm{X}_{1} . \mathrm{X}_{2}$ and $\mathrm{X}_{2} . \mathrm{X}_{3}$ are smaller than 0.05 , which concludes that the interaction between incubation temperature and moisture content is important and the interaction between moisture content and inoculum size. According to the previous study [51], the production of manganese peroxidase from Schyzophyllum commune and Ganoderma lucidum was optimized by using corn stover and banana stalk as solid substrates.

The interactions between the factors can also be explained by an interaction plot shown in Figure 3. The factors' interactions are weak if the lines are closed to parallel and vice versa [50]. Figure 3 presents many interactions: incubation temperature-moisture content $\left(X_{1} \cdot X_{2}\right)$, incubation temperature-inoculum size $\left(\mathrm{X}_{1} . \mathrm{X}_{3}\right)$, and moisture content-inoculum size $\left(\mathrm{X}_{2} . \mathrm{X}_{3}\right)$. The interaction plot of $\mathrm{X}_{1} . \mathrm{X}_{3}$ represents the interaction is less important, while the lines of incubation $\mathrm{X}_{1} \cdot \mathrm{X}_{2}$ and $\mathrm{X}_{2} . \mathrm{X}_{3}$ display the importance of the interactions on the protease yield.

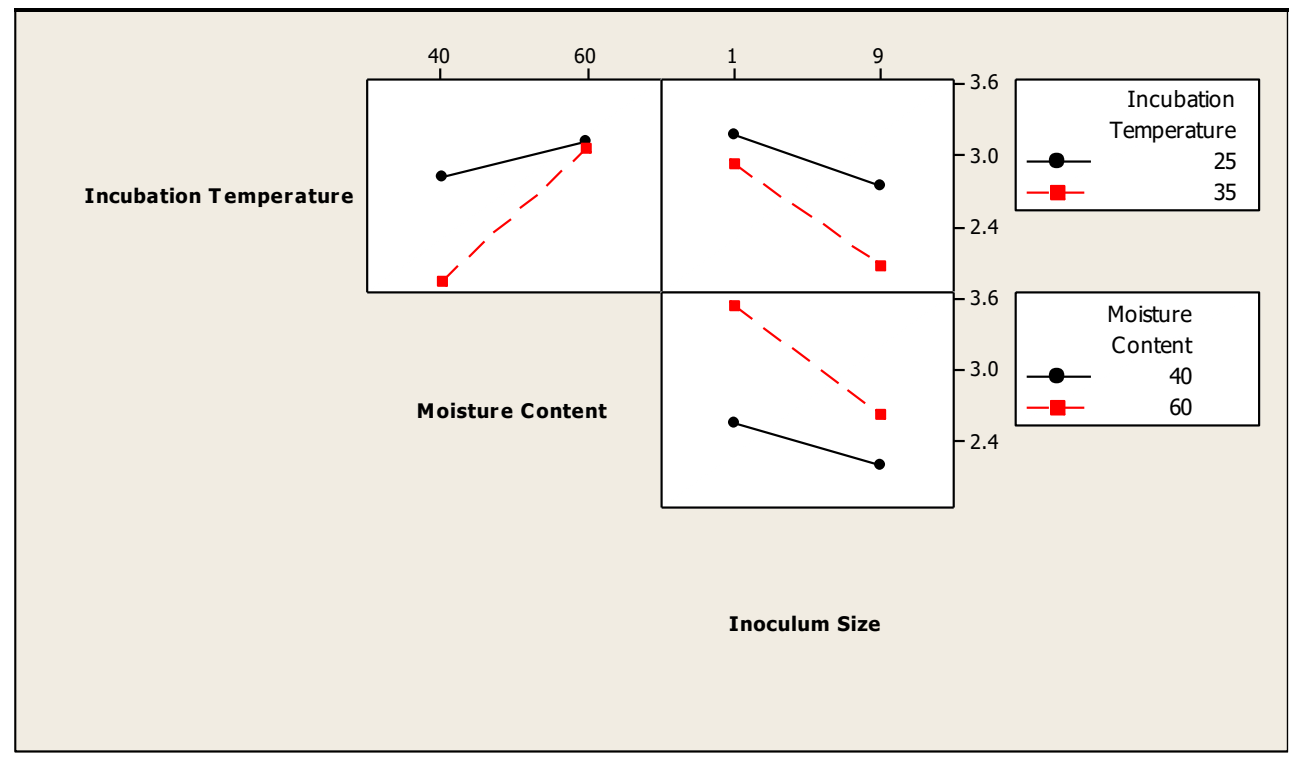

Figure 3. Interaction effects plot for protease production.

The significance of the main effects and their interactions can also be present on the Pareto chart and normal plot generated by Minitab. Figure 4 display the Pareto chart of the standardized effects. The values are considered significant if they exceed the reference line or vice versa [52]. From Figure 4, it is clearly showed that only AC and ABC represent the interaction between incubation temperature and inoculum size, and the interactions between all three factors are not significant as their values fall before the reference line, which is 2.120.

The normal plot is demonstrated in Figure 5. The red color points, which are far away from the line fitted to the middle, imply that those are significant main and interactions of 
factors. On the other hand, points in black color, close to the line, represent factors that do not significantly affect the response $[50,53]$.

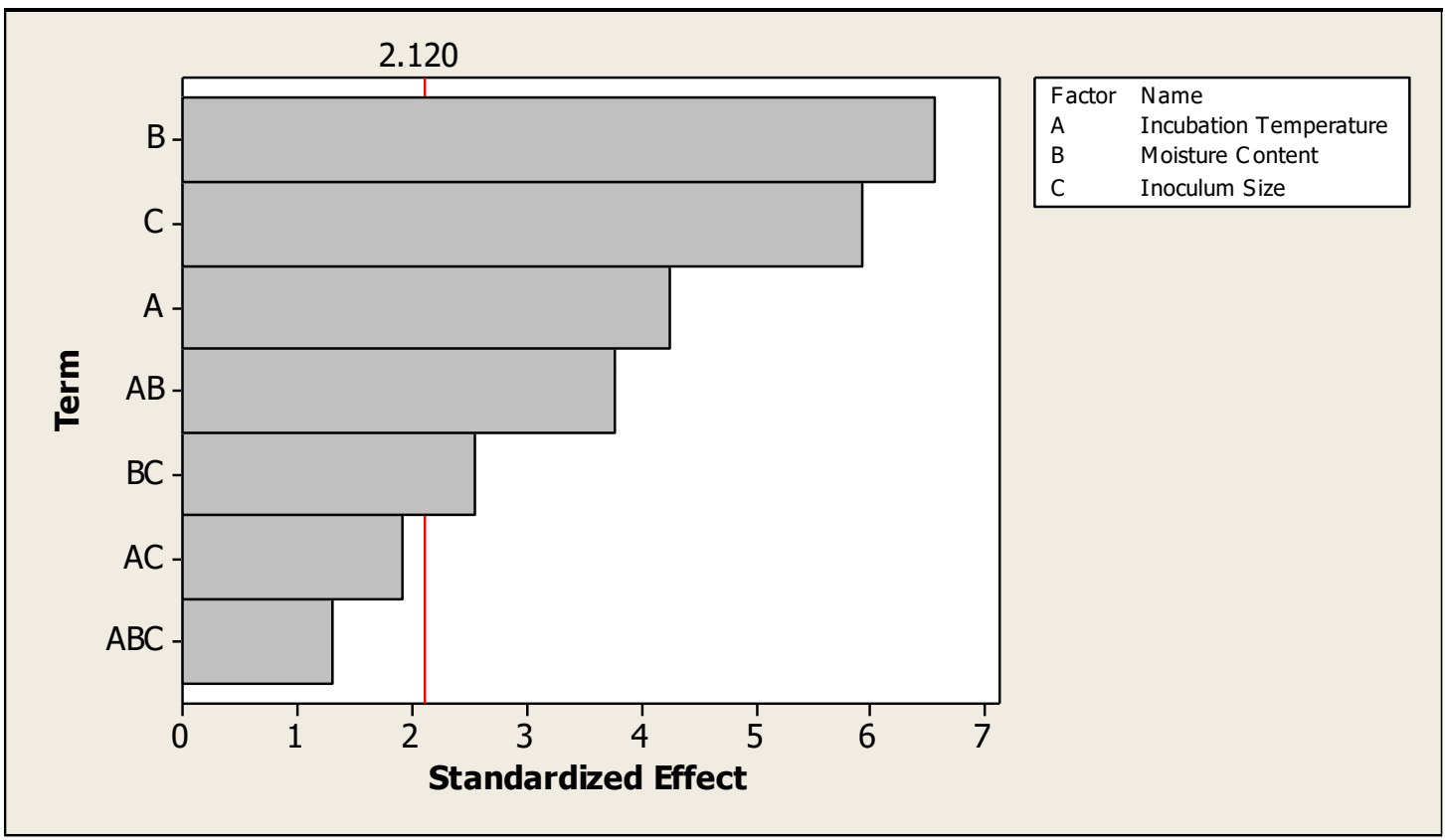

Figure 4. Pareto chart of the standardized effects (response is yield, alpha $=0.05$ ).

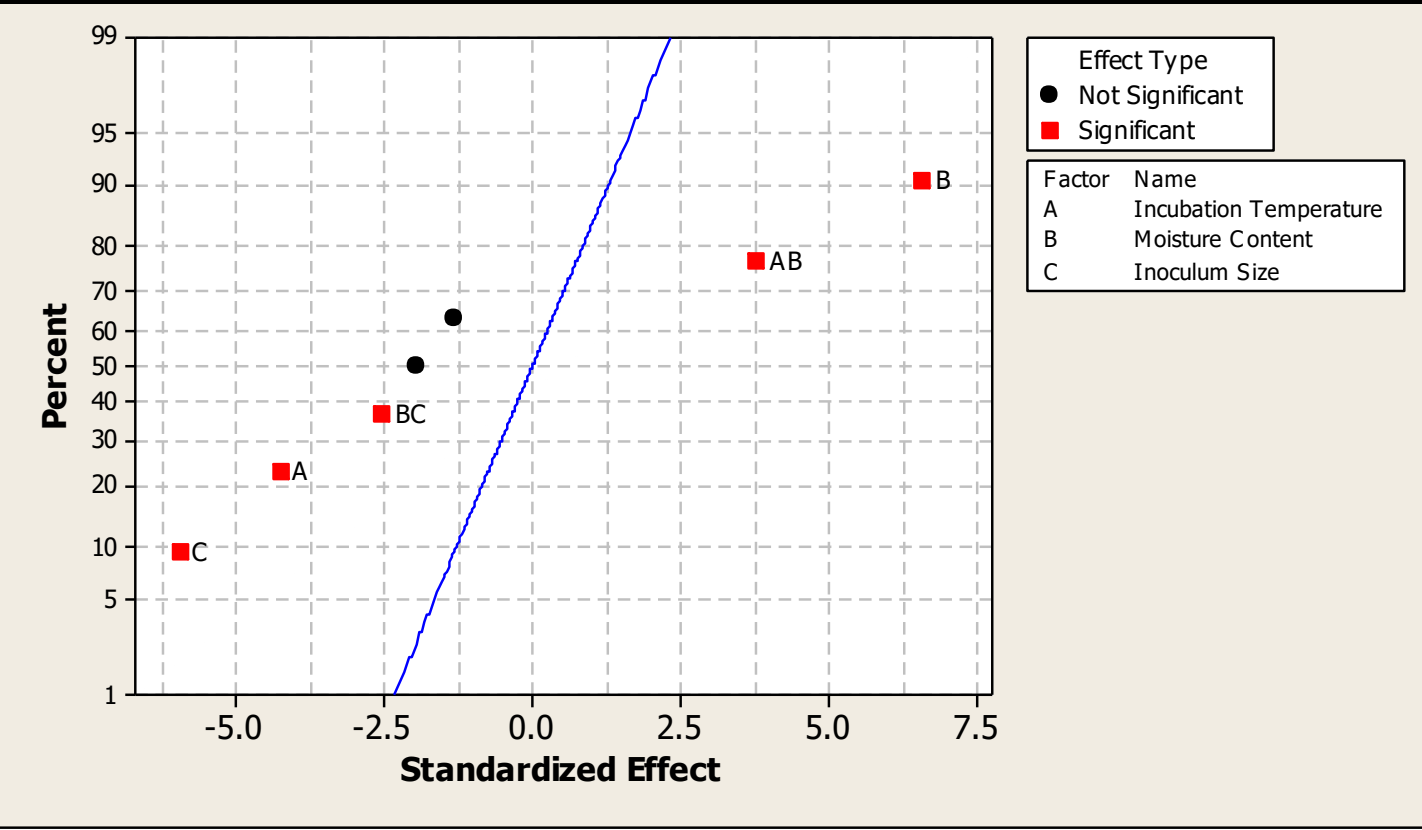

Figure 5. Normal plot of the standardized effects (response is yield, alpha $=0.05$ )

Contour and surface plots of all three variables were generated through Minitab to study further the relationship between the optimization factors and the yield of protease [54].

Figures 6(a) and (b) demonstrate the effect of incubation temperature and moisture content on protease production. From Figure 6, it is obviously showed that the interaction between incubation temperature and moisture content has a positive impact on protease yield. It is in accordance with the results shown in Table 3. The protease production increased as the incubation temperature increased together with the substrate's increment of moisture content. The interaction of these two factors is significant on the response variable, as explained in the normal plot in Figure 5. 
The interaction between incubation temperature and inoculum size on protease production is presented in Figures 7(a) and (b). From the plots, the interaction between these two factors has a negative effect on the protease yield. The yield of protease increases with the decrement of incubation temperature and inoculum size. This is inclined to the negative coefficient of $X_{1} \cdot X_{3}$, as shown in Table 3. However, the interaction between these two factors is not significant to protease production, as shown in the Pareto chart in Figure 4.

Figure 8(a) and (b) present the effect of interaction between moisture content and inoculum size on protease yield. From Figure 8, it is inferred that the yield of protease increases when the moisture content increases while the inoculum size decreases.

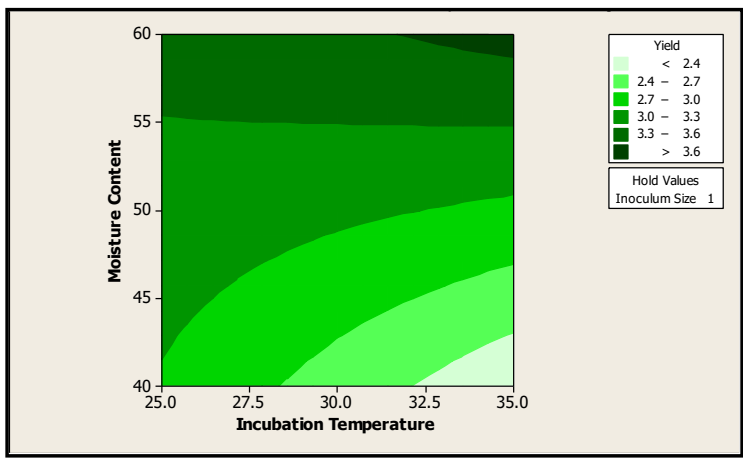

(a)

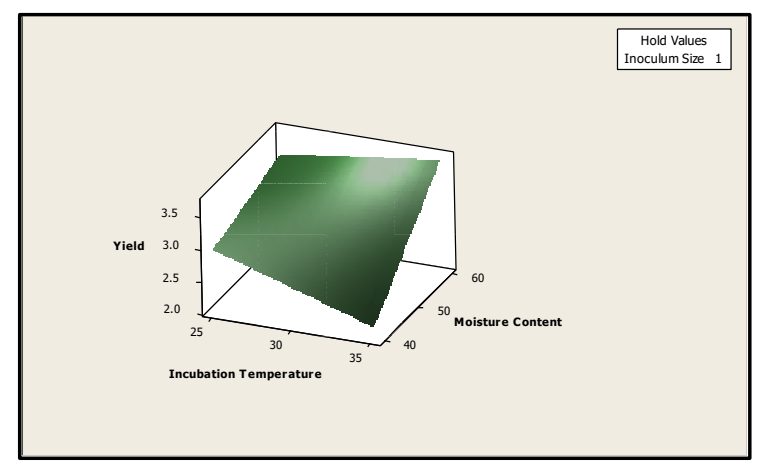

(b)

Figure 6. The effect of incubation temperature and moisture content on protease yield (a) contour plot; (b) surface plot.

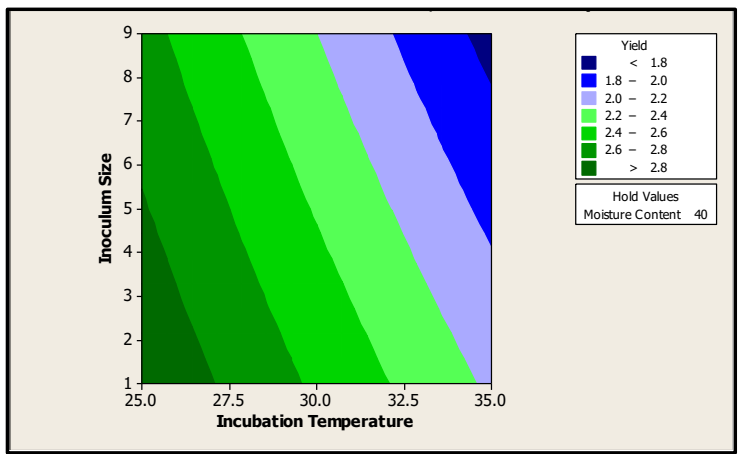

(a)

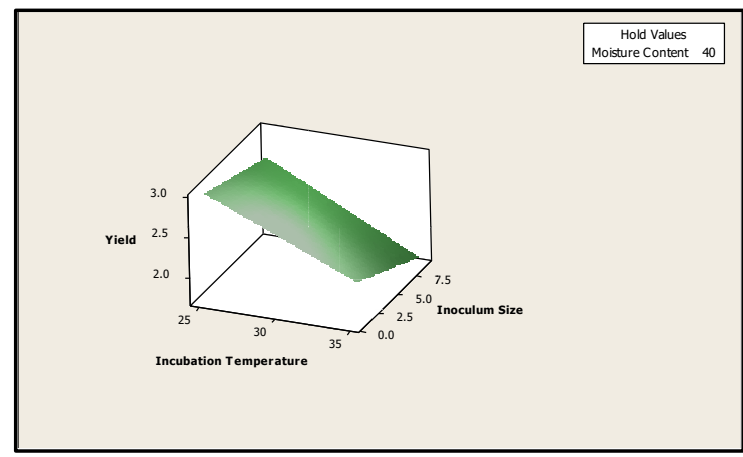

(b)

Figure 7. The effect of incubation temperature and inoculum size on protease yield (a) contour plot; (b) surface plot.

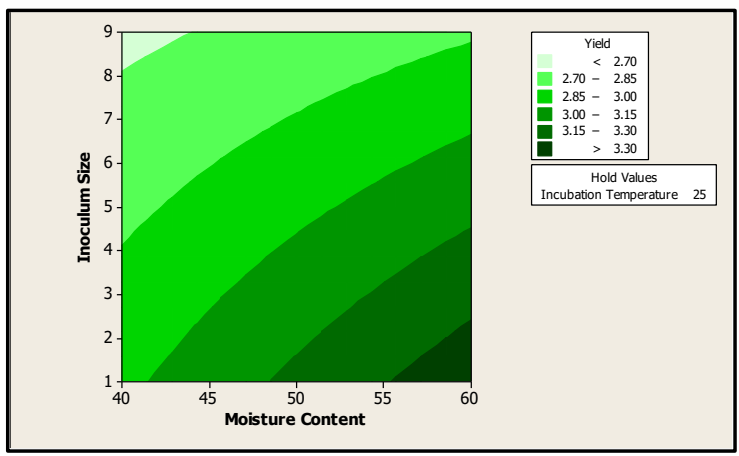

(a)

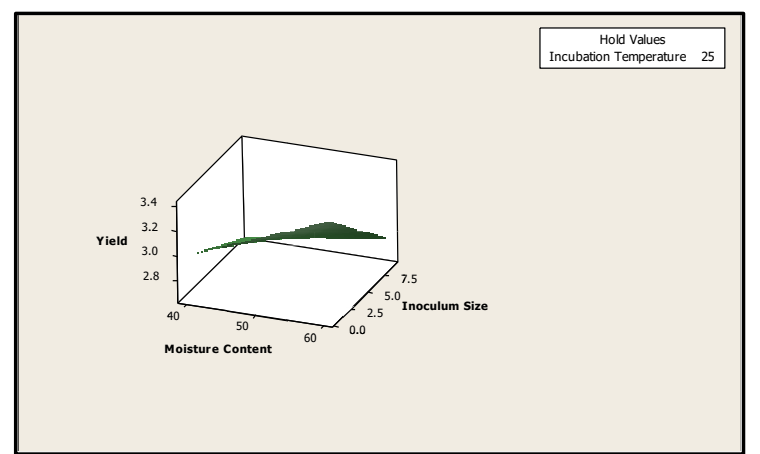

(b)

Figure 8. The effect of moisture content and inoculum size on protease yield (a) contour plot; (b) surface plot.

The interaction between moisture content and inoculum size significantly affects the response variable as interpreted in the Pareto chart and normal plot in Figure 4 and Figure 5, respectively. 


\subsubsection{Normal probability.}

A normal probability plot of residuals is constructed to determine the normality assumption of the data. An experiment's data are normally distributed if the data points are situated remarkably close to the plot's straight line [48, 49]. By referring to Figure 9, the data points are considerably close to the straight line. Thus, it is determined that the data were collected from a normally distributed population.

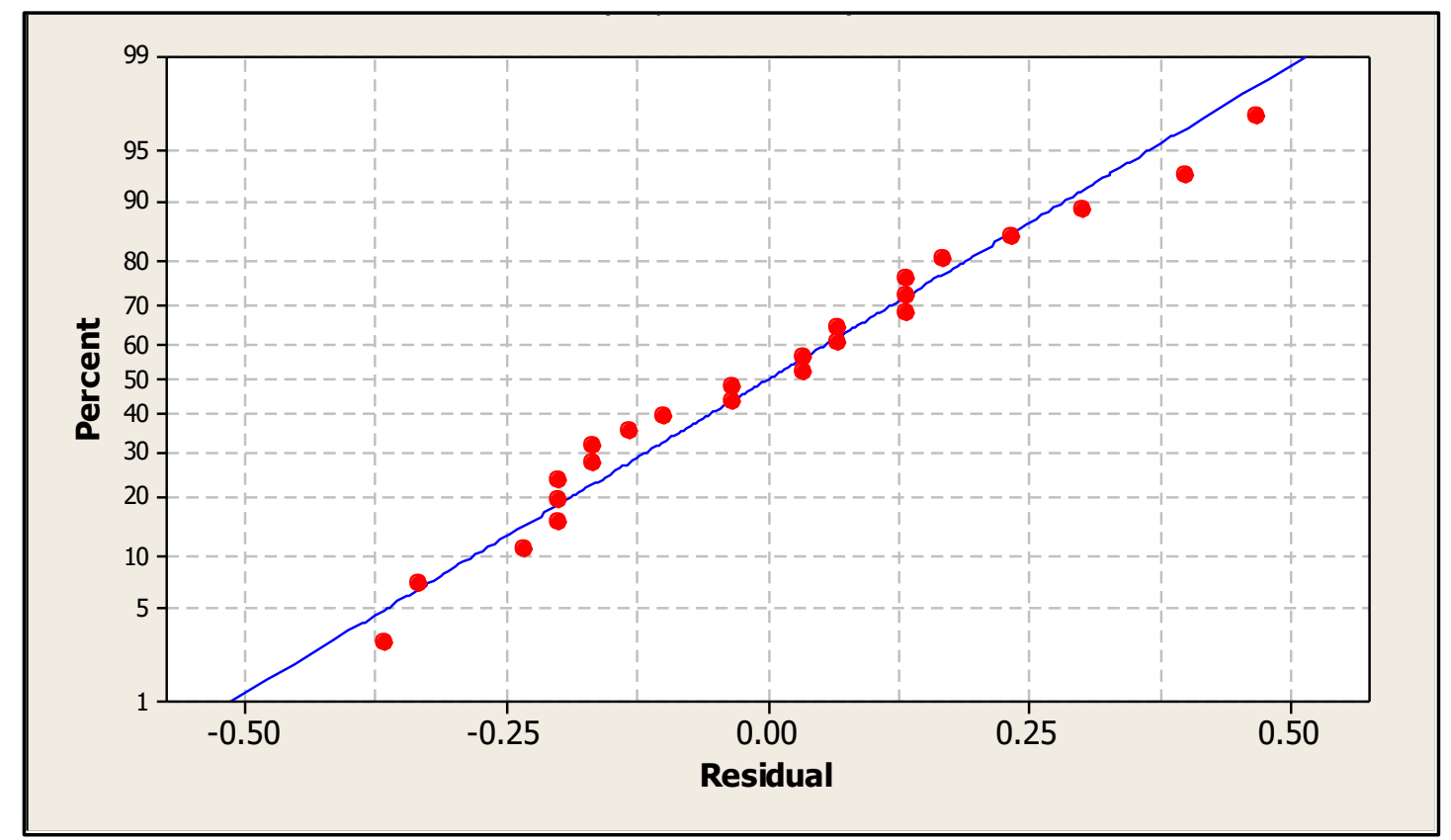

Table 9. Normal probability plot of residuals (response is yield).

\subsubsection{Optimal design conditions.}

To acquire the maximum protease yield, the method of desirability function was applied [36]. The optimum condition for the maximum production of protease was at $35{ }^{\circ} \mathrm{C}$ of incubation temperature, $60 \%$ of initial moisture content, and 1.0 inoculum size. This optimal combination of factor settings was introduced for the predicted response of $3.7 \mathrm{U} / \mathrm{mg}$ with a desirability value of 1.0000, as shown in Figure 10.

The results obtained from this study are approximately matched to studies by previous researchers. Production of xylanase under SSF with the influence of incubation temperature found out that the ideal temperature was maintained in the range of $30-35{ }^{\circ} \mathrm{C}$ based on the research from [55]. On the other hand, the optimal incubation temperature for amylase production was $37{ }^{\circ} \mathrm{C}$ in the study from [56]. For this study, $35^{\circ} \mathrm{C}$ is the optimum incubation temperature for protease production. At higher temperatures, the temperature of fermenting substrate rises due to a large amount of metabolic heat. It might inhibit microbial growth and slow down their metabolic activities due to the denaturation of proteins, leading to lesser enzyme formation $[57,58]$.

In this present study, $60 \%$ of moisture content was obtained as the optimal condition for protease production. According to the study from [19], it is in accordance with the production of cellulases from Aspergillus niger NS-2 and learned that substrate-moisture ratio of 1:1.5 (60.0\%) was most suitable for the production of cellulases under SSF. It would lead to poor solubility of the nutrient substrate at a lower moisture level, higher water tension, and lower degree of swelling, which would result in poor microbial growth. In contrast, higher 
moisture content would cause a decrease in substrate porosity. Thus, oxygen penetration is limited and eventually reduces fungi growth and enzyme formation [57, 59].

The optimum inoculum size for this study is 1.0, which indicates that only 1 petri dish of inoculum is needed for the maximum production of protease. As mentioned in subsection 3.2, 1 petri dish contains $1.59 \times 10^{6}$ pores/ml of Aspergillus niger inoculum. This result is almost matched to the study from [60]; the inoculum size for optimum production of alphaamylase from Aspergillus oryzae was $10^{6.87}$ by utilizing industrial waste residues. There are fewer conidial cells at a smaller inoculum size as a long time is required for the cell to duplicate. Conidial cells are insufficient for the initiation of microbial growth and production of the enzyme. In contrast, extremely large inoculum size results in decreased yield due to the high initial concentration of conidial cells. The cells' enormous growth causes depletion and imbalance of nutrients within a short period, resulting in lower metabolic activity [17, 19].

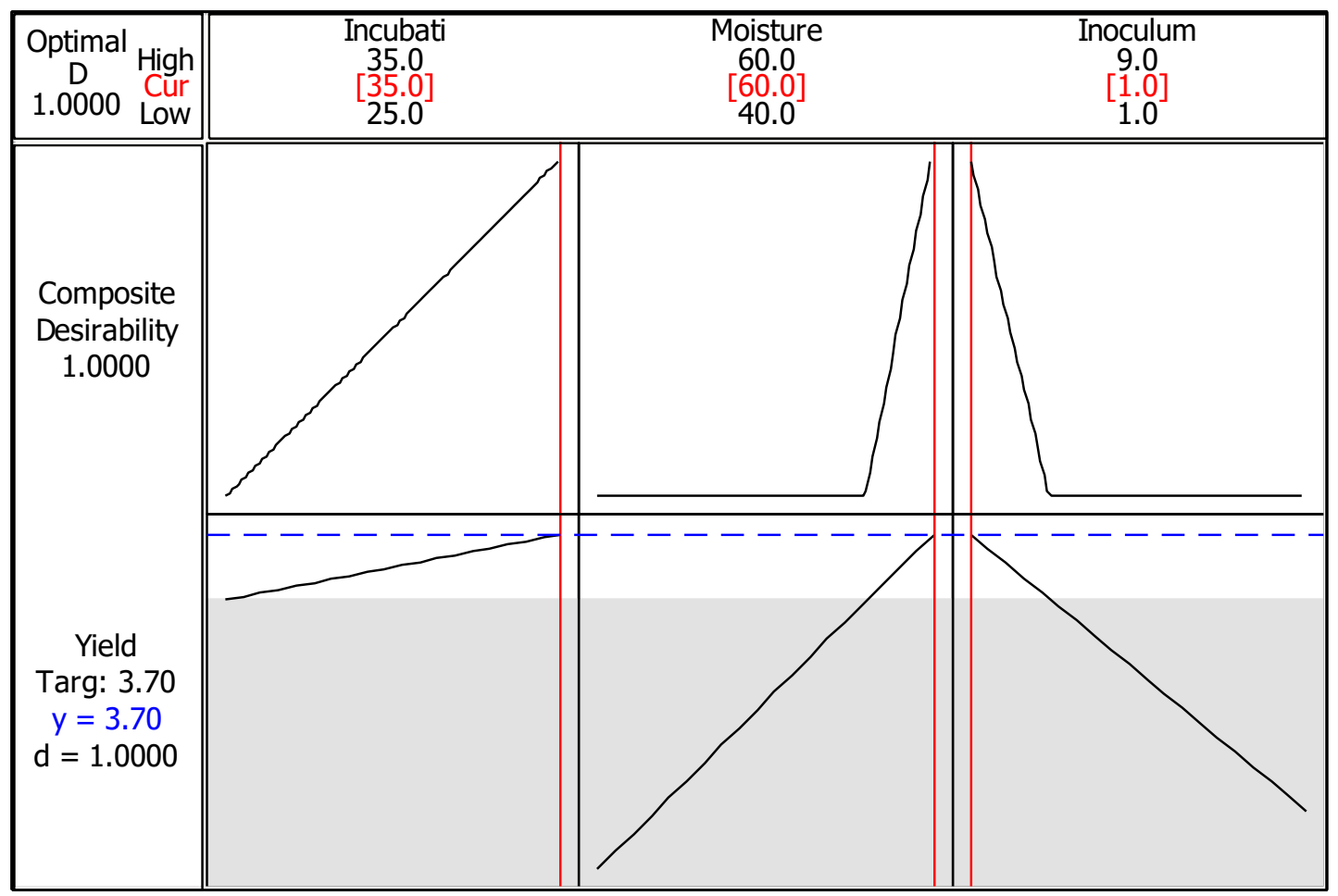

Figure 10. Desirability functions for the optimization of the response.

\section{Conclusions}

This study found out that the enzyme solution produced from Aspergillus niger under SSF was slightly alkaline. The enzyme produced was also tested for enzyme activity. The results indicate that it possessed protease activity. The correlation between factors operating parameters was studied by using Minitab 16. Incubation temperature, initial moisture content, and inoculum size were the factors in the design matrix. According to the statistical analysis, moisture content has a positive effect on the production of protease. It is also deduced that the interaction between incubation temperature and moisture content is significant and the interaction between moisture content and inoculum size.

Production of protease was optimized by employing a full factorial design. The maximum protease production was achieved at $35^{\circ} \mathrm{C}$ of incubation temperature, $60 \%$ of initial moisture content, and 1.0 inoculum size. Aquaculture sludge collected from Integrated Shrimp Aquaculture Park (iSHARP) Sdn Bhd was considered highly polluting wastewater. Due to the high content of organic material in the sludge, the COD value was extremely high. It was 
harmful to the environment, causing pollution and eutrophication. Besides, the sludge contained a high amount of TSS.

A batch test was conducted with SSF and commercial protease for the treatment of aquaculture sludge. The samples were left for digestion for 7 days. The results indicate that both proteases can be effectively used as an enzymatic treatment of aquaculture sludge. It was able to remove COD and TSS. The batch test showed a higher percentage of reduction of COD using commercial protease. The reduction percentage was 93.32\%. However, SSF protease was more economically friendly.

\section{Funding}

This research was funded by Fundamental Research Grant Scheme (FRGS) with project number 59347.

\section{Acknowledgments}

The authors wish to thank and acknowledge Universiti Malaysia Terengganu for all its assistance during this study.

\section{Conflicts of Interest}

The authors declare no conflict of interest. The funders had no role in the study's design, in the collection, analyses, or interpretation of data, in the writing of the manuscript, or in the decision to publish the results.

\section{References}

1. Karam, J.; Nicell, J.A. Potential applications of enzymes in waste treatment. Journal of Chemical Technology \& Biotechnology: International Research in Process, Environmental AND Clean Technology 1997, 69, 141153.

2. de Castro, R.J.S.; Ohara, A.; Nishide, T.G.; Bagagli, M.P.; Gonçalves Dias, F.F.; Sato, H.H. A versatile system based on substrate formulation using agroindustrial wastes for protease production by Aspergillus niger under solid state fermentation. Biocatalysis and Agricultural Biotechnology 2015, 4, 678-684, https://doi.org/10.1016/j.bcab.2015.08.010.

3. Briki, S.; Hamdi, O.; Landoulsi, A. Enzymatic dehairing of goat skins using alkaline protease from Bacillus sp. SB12. Protein Expression Purif. 2016, 121, 9-16, https://doi.org/10.1016/j.pep.2015.12.021.

4. Yazid, N.A.; Barrena, R.; Sánchez, A. Assessment of protease activity in hydrolysed extracts from SSF of hair waste by and indigenous consortium of microorganisms. Waste Manage. 2016, 49, 420-426, https://doi.org/10.1016/j.wasman.2016.01.045.

5. Iqbal, A.; Hakim, A.; Hossain, M.S.; Rahman, M.R.; Islam, K.; Azim, M.F.; Ahmed, J.; Assaduzzaman, M.; Hoq, M.M.; Azad, A.K. Partial purification and characterization of serine protease produced through fermentation of organic municipal solid wastes by Serratia marcescens A3 and Pseudomonas putida A2. Journal of Genetic Engineering and Biotechnology 2018, 16, 29-37, https://doi.org/10.1016/j.jgeb.2017.10.011.

6. Pandey, K.; Singh, B.; Pandey, A.K.; Badruddin, I.J.; Pandey, S.; Mishra, V.K.; Jain, P.A. Application of microbial enzymes in industrial waste water treatment. Int. J. Curr. Microbiol. Appl. Sci 2017, 6, 1243-1254, https://doi.org/10.20546/ijcmas.2017.608.151.

7. Gurumallesh, P.; Alagu, K.; Ramakrishnan, B.; Muthusamy, S. A systematic reconsideration on proteases. Int. J. Biol. Macromol. 2019, 128, 254-267, https://doi.org/10.1016/j.ijbiomac.2019.01.081.

8. Homaei, A.; Lavajoo, F.; Sariri, R. Development of marine biotechnology as a resource for novel proteases and their role in modern biotechnology. Int. J. Biol. Macromol. 2016, 88, 542-552, https://doi.org/10.1016/j.ijbiomac.2016.04.023. 
9. Asgher, M.; Bashir, F.; Iqbal, H.M.N. Protease-based cross-linked enzyme aggregates with improved catalytic stability, silver removal, and dehairing potentials. Int. J. Biol. Macromol. 2018, 118, 1247-1256, https://doi.org/10.1016/j.ijbiomac.2018.06.107.

10. Costa, R.d.S.; de Almeida, S.S.; Cavalcanti, E.d.A.C.; Freire, D.M.G.; Moura-Nunes, N.; Monteiro, M.; Perrone, D. Enzymes produced by solid state fermentation of agro-industrial by-products release ferulic acid in bioprocessed whole-wheat breads. Food Res. Int. 2021, 140, 109843, https://doi.org/10.1016/j.foodres.2020.109843.

11. Pandey, A. Solid-state fermentation. Biochem. Eng. J. 2003, 13, 81-84, https://doi.org/10.1016/S1369703X(02)00121-3.

14. Singhania, R.R.; Patel, A.K.; Soccol, C.R.; Pandey, A. Recent advances in solid-state fermentation. Biochem. Eng. J. 2009, 44, 13-18, https://doi.org/10.1016/j.bej.2008.10.019.

13. Soccol, C.R.; Costa, E.S.F.d.; Letti, L.A.J.; Karp, S.G.; Woiciechowski, A.L.; Vandenberghe, L.P.d.S. Recent developments and innovations in solid state fermentation. Biotechnology Research and Innovation 2017, 1, 52-71, https://doi.org/10.1016/j.biori.2017.01.002.

14. Xiao, L.; Yang, L.; Zhang, Y.; Gu, Y.; Jiang, L.; Qin, B. Solid state fermentation of aquatic macrophytes for crude protein extraction. Ecol. Eng. 2009, 35, 1668-1676, https://doi.org/10.1016/j.ecoleng.2008.08.004.

15. Thomas, L.; Larroche, C.; Pandey, A. Current developments in solid-state fermentation. Biochem. Eng. J. 2013, 81, 146-161, https://doi.org/10.1016/j.bej.2013.10.013.

16. Suresh, P.V.; Sachindra, N.M.; Bhaskar, N. Solid state fermentation production of chitin deacetylase by Colletotrichum lindemuthianum ATCC 56676 using different substrates. J. Food Sci. Technol. 2011, 48, 349356, https://doi.org/10.1007/s13197-011-0252-0.

17. Meghavarnam, A.K.; Janakiraman, S. Solid state fermentation: An effective fermentation strategy for the production of L-asparaginase by Fusarium culmorum (ASP-87). Biocatalysis and Agricultural Biotechnology 2017, 11, 124-130, https://doi.org/10.1016/j.bcab.2017.06.001.

18. Farinas, C.S. Developments in solid-state fermentation for the production of biomass-degrading enzymes for the bioenergy sector. Renewable and Sustainable Energy Reviews 2015, 52, 179-188, https://doi.org/10.1016/j.rser.2015.07.092.

19. Bansal, N.; Tewari, R.; Soni, R.; Soni, S.K. Production of cellulases from Aspergillus niger NS-2 in solid state fermentation on agricultural and kitchen waste residues. Waste Manage. 2012, 32, 1341-1346, https://doi.org/10.1016/j.wasman.2012.03.006.

20. Nidheesh, T.; Pal, G.K.; Suresh, P.V. Chitooligomers preparation by chitosanase produced under solid state fermentation using shrimp by-products as substrate. Carbohydr. Polym. 2015, 121, 1-9, https://doi.org/10.1016/j.carbpol.2014.12.017.

21. Matkawala, F.; Nighojkar, S.; Kumar, A.; Nighojkar, A. Enhanced production of alkaline protease by Neocosmospora sp. N1 using custard apple seed powder as inducer and its application for stain removal and dehairing. Biocatalysis and Agricultural Biotechnology 2019, 21, 101310 , https://doi.org/10.1016/j.bcab.2019.101310.

22. do Nascimento, F.V.; de Castro, A.M.; Secchi, A.R.; Coelho, M.A.Z. Insights into media supplementation in solid-state fermentation of soybean hulls by Yarrowia lipolytica: Impact on lipase production in tray and insulated packed-bed bioreactors. Biochem. Eng. J. 2021, 166, 107866, https://doi.org/10.1016/j.bej.2020.107866.

23. Zheng, L.; Yu, X.; Wei, C.; Qiu, L.; Yu, C.; Xing, Q.; Fan, Y.; Deng, Z. Production and characterization of a novel alkaline protease from a newly isolated Neurospora crassa through solid-state fermentation. $L W T$ 2020, 122, 108990, https://doi.org/10.1016/j.lwt.2019.108990.

24. Ambigaipalan, P.; Shahidi, F. Bioactive peptides from shrimp shell processing discards: Antioxidant and biological activities. J. Funct. Foods 2017, 34, 7-17, https://doi.org/10.1016/j.jff.2017.04.013.

25. Food and Agriculture Organization of the United Nations [FAO]. The State of World Fisheries and Aquaculture 2020. Sustainability in action. Rome 2020, https://doi.org/10.4060/ca9229en.

26. Suresh, P.V. Biodegradation of shrimp processing bio-waste and concomitant production of chitinase enzyme and N-acetyl-D-glucosamine by marine bacteria: production and process optimization. World J. Microbiol. Biotechnol. 2012, 28, 2945-2962, https://doi.org/10.1007/s11274-012-1106-2.

27. Cheba, B.A.; Zaghloul, T.I.; El-Mahdy, A.R. Demineralized crab and shrimp shell powder: Cost effective medium for bacillus Sp. R2 growth and chitinase production. Procedia Manufacturing 2018, 22, 413-419, https://doi.org/10.1016/j.promfg.2018.03.065. 
28. Wang, S.-L.; Liang, T.-W.; Yen, Y.-H. Bioconversion of chitin-containing wastes for the production of enzymes and bioactive materials. Carbohydr. Polym. 2011, 84, 732-742, https://doi.org/10.1016/j.carbpol.2010.06.022.

29. Nasir, N.M.; Bakar, N.S.A.; Lananan, F.; Abdul Hamid, S.H.; Lam, S.S.; Jusoh, A. Treatment of African catfish, Clarias gariepinus wastewater utilizing phytoremediation of microalgae, Chlorella sp. with Aspergillus niger bio-harvesting. Bioresour. Technol. 2015, 190, 492-498, https://doi.org/10.1016/j.biortech.2015.03.023.

30. Sandri, I.G.; Silveira, M.M. Production and Application of Pectinases from Aspergillus niger Obtained in Solid State Cultivation. Beverages 2018, 4, https://doi.org/10.3390/beverages4030048.

31. Sandoval-Contreras, T.; Marín, S.; Villarruel-López, A.; Gschaedler, A.; Garrido-Sánchez, L.; Ascencio, F. Growth Modeling of Aspergillus niger Strains Isolated from Citrus Fruit as a Function of Temperature on a Synthetic Medium from Lime (Citrus latifolia T.) Pericarp. J. Food Prot. 2017, 80, 1090-1098, https://doi.org/10.4315/0362-028X.JFP-16-408.

32. Kumari, S.; Kumar Annamareddy, S.H.; Abanti, S.; Kumar Rath, P. Physicochemical properties and characterization of chitosan synthesized from fish scales, crab and shrimp shells. Int. J. Biol. Macromol. 2017, 104, 1697-1705, https://doi.org/10.1016/j.ijbiomac.2017.04.119.

33. Maruthiah, T.; Palavesam, A. Characterization of haloalkalophilic organic solvent tolerant protease for chitin extraction from shrimp shell waste. Int. J. Biol. Macromol. 2017, 97, 552-560, https://doi.org/10.1016/j.ijbiomac.2017.01.021.

34. Kumar, L.; Sreenivasa Reddy, M.; Managuli, R.S.; Pai K, G. Full factorial design for optimization, development and validation of HPLC method to determine valsartan in nanoparticles. Saudi Pharmaceutical Journal 2015, 23, 549-555, https://doi.org/10.1016/j.jsps.2015.02.001.

35. Lhanafi, S.; Anfar, Z.; Chebli, B.; Benafqir, M.; El Haouti, R.; Azougarh, Y.; Abbaz, M.; El Alem, N. Factorial experimental design to enhance methane production of dairy wastes co-digestion. Sustainable Environment Research 2018, 28, 389-395, https://doi.org/10.1016/j.serj.2018.05.001.

36. Hank, D.; Azi, Z.; Ait Hocine, S.; Chaalal, O.; Hellal, A. Optimization of phenol adsorption onto bentonite by factorial design methodology. Journal of Industrial and Engineering Chemistry 2014, 20, 2256-2263, https://doi.org/10.1016/j.jiec.2013.09.058.

37. Anjugam, M.; Vaseeharan, B.; Iswarya, A.; Amala, M.; Govindarajan, M.; Alharbi, N.S.; Kadaikunnan, S.; Khaled, J.M.; Benelli, G. A study on $\beta$-glucan binding protein ( $\beta$-GBP) and its involvement in phenoloxidase cascade in Indian white shrimp Fenneropenaeus indicus. Mol. Immunol. 2017, 92, 1-11, https://doi.org/10.1016/j.molimm.2017.09.013.

38. Dang, T.T.; Gringer, N.; Jessen, F.; Olsen, K.; Bøknæs, N.; Nielsen, P.L.; Orlien, V. Facilitating shrimp (Pandalus borealis) peeling by power ultrasound and proteolytic enzyme. Innov. Food Sci. Emerg. Technol. 2018, 47, 525-534, https://doi.org/10.1016/j.ifset.2018.04.019.

39. Zheng, F.-Y.; Li, R.; Hu, J.; Zhang, J.; Han, X.; Wang, X.; Xu, W.-R.; Zhang, Y. Chitin and waste shrimp shells liquefaction and liquefied products/polyvinyl alcohol blend membranes. Carbohydr. Polym. 2019, 205, 550-558, https://doi.org/10.1016/j.carbpol.2018.10.079.

40. Yuan, G.; Jia, Y.; Pan, Y.; Li, W.; Wang, C.; Xu, L.; Wang, C.; Chen, H. Preparation and characterization of shrimp shell waste protein-based films modified with oolong tea, corn silk and black soybean seed coat extracts. Polym. Test. 2020, 81, 106235, https://doi.org/10.1016/j.polymertesting.2019.106235.

41. Wang, S.-L.; Chen, Y.-H.; wang, C.-L.; Yen, Y.-H.; chern, M.-K. Purification and characterization of a serine protease extracellularly produced by Aspergillus fumigatus in a shrimp and crab shell powder medium. Enzyme Microb. Technol. 2005, 36, 660-665, https://doi.org/10.1016/j.enzmictec.2004.10.006.

42. de Castro, R.J.S.; Nishide, T.G.; Sato, H.H. Production and biochemical properties of proteases secreted by Aspergillus niger under solid state fermentation in response to different agroindustrial substrates. Biocatalysis and Agricultural Biotechnology 2014, 3, 236-245, https://doi.org/10.1016/j.bcab.2014.06.001.

43. Aliyah, A.; Alamsyah, G.; Ramadhani, R.; Hermansyah, H. Production of $\alpha$-Amylase and $\beta$-Glucosidase from Aspergillus niger by solid state fermentation method on biomass waste substrates from rice husk, bagasse and corn cob. Energy Procedia 2017, 136, 418-423, https://doi.org/10.1016/j.egypro.2017.10.269.

44. Utami, T.S.; Hariyani, I.; Alamsyah, G.; Hermansyah, H. Production of dry extract extracellular lipase from Aspergillus niger by solid state fermentation method to catalyze biodiesel synthesis. Energy Procedia 2017, 136, 41-46, https://doi.org/10.1016/j.egypro.2017.10.275. 
45. Liang, T.-W.; Lin, J.-J.; Yen, Y.-H.; Wang, C.-L.; Wang, S.-L. Purification and characterization of a protease extracellularly produced by Monascus purpureus CCRC31499 in a shrimp and crab shell powder medium. Enzyme Microb. Technol. 2006, 38, 74-80, https://doi.org/10.1016/j.enzmictec.2005.04.023.

46. Maruthiah, T.; Somanath, B.; Immanuel, G.; Palavesam, A. Deproteinization potential and antioxidant property of haloalkalophilic organic solvent tolerant protease from marine Bacillus sp. APCMST-RS3 using marine shell wastes. Biotechnology Reports 2015, 8, 124-132, https://doi.org/10.1016/j.btre.2015.10.009.

47. Wang, S.-L.; Yeh, P.-Y. Production of a surfactant- and solvent-stable alkaliphilic protease by bioconversion of shrimp shell wastes fermented by Bacillus subtilis TKU007. Process Biochem. 2006, 41, 1545-1552, https://doi.org/10.1016/j.procbio.2006.02.018.

48. Seyed Shahabadi, S.M.; Reyhani, A. Optimization of operating conditions in ultrafiltration process for produced water treatment via the full factorial design methodology. Sep. Purif. Technol. 2014, 132, 50-61, https://doi.org/10.1016/j.seppur.2014.04.051.

49. Camacho, L.M.; Fox, J.A.; Ajedegba, J.O. Optimization of electrodialysis metathesis (EDM) desalination using factorial design methodology. Desalination 2017, 403, 136-143, https://doi.org/10.1016/j.desal.2016.07.028.

50. Regti, A.; El Kassimi, A.; Laamari, M.R.; El Haddad, M. Competitive adsorption and optimization of binary mixture of textile dyes: A factorial design analysis. Journal of the Association of Arab Universities for Basic and Applied Sciences 2017, 24, 1-9, https://doi.org/10.1016/j.jaubas.2016.07.005.

51. Yasmeen, Q.; Asgher, M.; Sheikh, M.A.; Nawaz, H. Optimization of ligninolytic enzymes production through response surface methodology. Bioresources 2013, 8, 944-968, https://doi.org/10.15376/biores.8.1.944-968.

52. Omar, M.A.; Ahmed, H.M.; Batakoushy, H.A.; Abdel Hamid, M.A. New spectrofluorimetric analysis of empagliflozin in its tablets and human plasma using two level full factorial design. Spectrochimica Acta Part A: Molecular and Biomolecular Spectroscopy 2020, 235, 118307, https://doi.org/10.1016/j.saa.2020.118307.

53. El-Shorbagy, H.I.; Elsebaei, F.; Hammad, S.F.; El-Brashy, A.M. Optimization and modeling of a green dual detected RP-HPLC method by UV and fluorescence detectors using two level full factorial design for simultaneous determination of sofosbuvir and ledipasvir: Application to average content and uniformity of dosage unit testing. Microchem. J. 2019, 147, 374-392, https://doi.org/10.1016/j.microc.2019.03.039.

54. Mohammed, I.h.A.; Bankole, M.T.; Abdulkareem, A.S.; Ochigbo, S.S.; Afolabi, A.S.; Abubakre, O.K. Full factorial design approach to carbon nanotubes synthesis by CVD method in argon environment. South African Journal of Chemical Engineering 2017, 24, 17-42, https://doi.org/10.1016/j.sajce.2017.06.001.

55. Lu, W.; Li, D.; Wu, Y. Influence of water activity and temperature on xylanase biosynthesis in pilot-scale solid-state fermentation by Aspergillus sulphureus. Enzyme Microb. Technol. 2003, 32, 305-311, https://doi.org/10.1016/S0141-0229(02)00292-2.

56. Hasan, M.M.; Marzan, L.W.; Hosna, A.; Hakim, A.; Azad, A.K. Optimization of some fermentation conditions for the production of extracellular amylases by using Chryseobacterium and Bacillus isolates from organic kitchen wastes. Journal of Genetic Engineering and Biotechnology 2017, 15, 59-68, https://doi.org/10.1016/j.jgeb.2017.02.009.

57. Bhatti, H.N.; Rashid, M.H.; Nawaz, R.; Asgher, M.; Perveen, R.; Jabbar, A. Optimization of media for enhanced glucoamylase production in solid-state fermentation by Fusarium solani. Food Technol. Biotechnol. 2007, 45, 51-56.

58. Sahu, R.; Meghavarnam, A.K.; Janakiraman, S. Response surface methodology: An effective optimization strategy for enhanced production of nitrile hydratase (NHase) by Rhodococcus rhodochrous (RS-6). Heliyon 2020, 6, e05111, https://doi.org/10.1016/j.heliyon.2020.e05111.

59. Rashid, J.I.; Samat, N.; Mohtar, W.; Yusoff, W. Optimization of temperature, moisture content and inoculum size in solid state fermentation to enhance mannanase production by Aspergillus terreus SUK-1 using RSM. Pakistan journal of biological sciences: PJBS 2011, 14, 533-539, https://doi.org/10.3923/pjbs.2011.533.539.

60. Sahnoun, M.; Kriaa, M.; Elgharbi, F.; Ayadi, D.-Z.; Bejar, S.; Kammoun, R. Aspergillus oryzae S2 alphaamylase production under solid state fermentation: Optimization of culture conditions. Int. J. Biol. Macromol. 2015, 75, 73-80, https://doi.org/10.1016/j.ijbiomac.2015.01.026. 